\title{
Comparison of Square and Radial Geometries for High Intensity Laser Power Beaming Receivers
}

Daniel E. Raible

Glenn Research Center, Cleveland, Ohio

Brian R. Fast

Rockwell Automation, Cleveland, Ohio

Dragos Dinca

Glenn Research Center, Cleveland, Ohio

Taysir H. Nayfeh

Cleveland State University, Cleveland, Ohio

Andrew K. Jalics

QinetiQ North America, Cleveland, Ohio 


\section{NASA STI Program . . . in Profile}

Since its founding, NASA has been dedicated to the advancement of aeronautics and space science. The NASA Scientific and Technical Information (STI) program plays a key part in helping NASA maintain this important role.

The NASA STI Program operates under the auspices of the Agency Chief Information Officer. It collects, organizes, provides for archiving, and disseminates NASA's STI. The NASA STI program provides access to the NASA Aeronautics and Space Database and its public interface, the NASA Technical Reports Server, thus providing one of the largest collections of aeronautical and space science STI in the world. Results are published in both non-NASA channels and by NASA in the NASA STI Report Series, which includes the following report types:

- TECHNICAL PUBLICATION. Reports of completed research or a major significant phase of research that present the results of NASA programs and include extensive data or theoretical analysis. Includes compilations of significant scientific and technical data and information deemed to be of continuing reference value. NASA counterpart of peer-reviewed formal professional papers but has less stringent limitations on manuscript length and extent of graphic presentations.

- TECHNICAL MEMORANDUM. Scientific and technical findings that are preliminary or of specialized interest, e.g., quick release reports, working papers, and bibliographies that contain minimal annotation. Does not contain extensive analysis.

- CONTRACTOR REPORT. Scientific and technical findings by NASA-sponsored contractors and grantees.
- CONFERENCE PUBLICATION. Collected papers from scientific and technical conferences, symposia, seminars, or other meetings sponsored or cosponsored by NASA.

- SPECIAL PUBLICATION. Scientific, technical, or historical information from NASA programs, projects, and missions, often concerned with subjects having substantial public interest.

- TECHNICAL TRANSLATION. Englishlanguage translations of foreign scientific and technical material pertinent to NASA's mission.

Specialized services also include creating custom thesauri, building customized databases, organizing and publishing research results.

For more information about the NASA STI program, see the following:

- Access the NASA STI program home page at http://www.sti.nasa.gov

- E-mail your question via the Internet to help@ sti.nasa.gov

- Fax your question to the NASA STI Help Desk at $443-757-5803$

- Telephone the NASA STI Help Desk at 443-757-5802

- Write to: NASA Center for AeroSpace Information (CASI) 7115 Standard Drive Hanover, MD 21076-1320 


\section{Comparison of Square and Radial Geometries for High Intensity Laser Power Beaming Receivers}

Daniel E. Raible

Glenn Research Center, Cleveland, Ohio

Brian R. Fast

Rockwell Automation, Cleveland, Ohio

Dragos Dinca

Glenn Research Center, Cleveland, Ohio

Taysir H. Nayfeh

Cleveland State University, Cleveland, Ohio

Andrew K. Jalics

QinetiQ North America, Cleveland, Ohio

Prepared for the

International Conference on Space Optical Systems and Applications (ICSOS)

sponsored by the Institute of Electrical and Electronics Engineers

Santa Monica, California, May 11-13, 2011

National Aeronautics and

Space Administration

Glenn Research Center

Cleveland, Ohio 44135 


\section{Acknowledgments}

This work was conducted by the Industrial Space Systems Laboratory (ISSL) at Cleveland State University under grant from the AFRL-Revolutionary Munitions Directorate at Eglin AFB. The ISSL team would like to express their thanks to: Bernie Sater and Greenfield Solar for the advice given to the ISSL from years of experience developing the VMJ cells. Jim Soeder, Ray Beach, Fred Wolff, and the NASA John H. Glenn Research Center for supporting the efforts of the ISSL. Ken Edwards and the Eglin Air Force Research Laboratory for the research partnership with the ISSL in further developing this technology. Hobson Lane, Bob Rice, and Northrop Grumman's Space Technology division for the time and support given to the ISSL during the demonstrations. NASA's Space Communications and Navigation (SCaN) program for supporting the publication and presentation of this research.

Trade names and trademarks are used in this report for identification only. Their usage does not constitute an official endorsement, either expressed or implied, by the National Aeronautics and Space Administration.

Level of Review: This material has been technically reviewed by technical management.

Available from

NASA Center for Aerospace Information 7115 Standard Drive Hanover, MD 21076-1320
National Technical Information Service 5301 Shawnee Road Alexandria, VA 22312 


\title{
Comparison of Square and Radial Geometries for High Intensity Laser Power Beaming Receivers
}

\author{
Daniel E. Raible \\ National Aeronautics and Space Administration \\ Glenn Research Center \\ Cleveland, Ohio 44135 \\ Brian R. Fast \\ Rockwell Automation \\ Cleveland, Ohio 44124 \\ Dragos Dinca \\ National Aeronautics and Space Administration \\ Glenn Research Center \\ Cleveland, Ohio 44135 \\ Taysir H. Nayfeh \\ Cleveland State University \\ Cleveland, Ohio 44115 \\ Andrew K. Jalics \\ QinetiQ North America \\ Cleveland, Ohio 44135
}

\begin{abstract}
In an effort to further advance a realizable form of wireless power transmission (WPT), high intensity laser power beaming (HILPB) has been developed for both space and terrestrial applications. Unique optical-to-electrical receivers are employed with near infrared (IR-A) continuous-wave (CW) semiconductor lasers to experimentally investigate the HILPB system. In this paper, parasitic feedback, uneven illumination and the implications of receiver array geometries are considered and experimental hardware results for HILPB are presented. The $\mathrm{TEM}_{00}$ Gaussian energy profile of the laser beam presents a challenge to the effectiveness of the receiver to perform efficient photoelectric conversion, due to the resulting nonuniform illumination of the photovoltaic cell arrays. In this investigation, the geometry of the receiver is considered as a technique to tailor the receiver design to accommodate the Gaussian beam profile, and in doing so it is demonstrated that such a methodology is successful in generating bulk receiver output power levels reaching $25 \mathrm{~W}$ from $7.2 \mathrm{~cm}^{2}$ of photovoltaic cells. These results are scalable, and may be realized by implementing receiver arraying and utilizing higher power source lasers to achieve a $1.0 \mathrm{~m}^{2}$ receiver capable of generating over $30 \mathrm{~kW}$ of electrical power. This type of system would enable long range optical "refueling" of electric platforms, such as MUAV's, airships, robotic exploration missions and provide power to spacecraft platforms which may utilize it to drive electric means of propulsion. In addition, a smaller HILPB receiver aperture size could be utilized to
\end{abstract}

establish a robust optical communications link within environments containing high levels of background radiance, to achieve high signal to noise ratios.

\subsection{Introduction}

In the $20^{\text {th }}$ and $21^{\text {st }}$ century, we as a society have become increasingly dependent on the immediate availability of electrical power. Electrical power is a commodity that is especially valuable for military operations and emergency first responders. However, many times the nature of these missions do not offer the convenient luxury of flipping a switch to instantaneously receive electrical power. These operations often require assets to be placed into remote locations where conventional power delivery infrastructures do not exist or may have been disrupted. Therefore other means of distributing electrical power are being investigated to meet these particularly challenging needs. These methods would not require large physical infrastructures and are known as wireless power transmission (WPT). This technology is similar to the wireless telecommunications industry. Cellular phones have grown in popularity over the past decades due to the availability, reliability, and the low associated cost. In areas where conventional land-based communications lines do not exist such as remote villages, wireless technology has become the standard method of electronic communication. In a similar manner, WPT may be used to enable power delivery to areas where conventional transmission lines would be prohibitively expensive, or technically infeasible. 
The WPT system would consist of a source, to transmit energy wirelessly, and a receiver, to collect and convert the energy either for immediate use or storage. Removing the transmission lines significantly increases the flexibility and capability during military operations and emergency missions. However, removing the distribution lines adds significant engineering challenges for providing sufficient energy in a reliable manner. One specific WPT technology includes high intensity laser power beaming (HILPB). HILPB consists of a high energy laser that would transmit optical energy at a specific target, for the purpose of providing remote power and potential high bandwidth communications capability. The target would consist of an optical receiver optimized to maximize the power conversion process from optical to electrical energy. This paper will specifically investigate the performance and scalability of the power receiver.

At the core of the power receiver is a single Vertical MultiJunction (VMJ) photovoltaic cell. The small $0.8 \mathrm{~cm}$ VMJ cell is essentially 40 vertically oriented current sources connected in series (Refs. 1 and 2). The cell is radically different from traditional photovoltaic devices due to its ability generate large current densities on the order of watts-per-square centimeter, while delivering a nominal $24 \mathrm{~V}$ under load (Ref. 3). The primary limitation of this type of cell is apparent when the illumination of the cell is non-uniform, which is the typical unconditioned $\mathrm{TEM}_{00}$ Gaussian case from most laser sources (Ref. 4). In this condition, one junction suffers from a lower level of illumination than its neighboring junctions, and the bulk output current of the cell will be limited by the single lowest capacity junction. Therefore, when designing a larger array which includes multiple VMJ cells the type of illumination across the cell becomes a major design consideration. This paper will examine multiple types of geometric arrangements and analyze the performance of the entire power receiver when illuminated by a laser that exhibits a typical $\mathrm{TEM}_{00}$ Gaussian profile. The arrangements will include an optimization of the VMJ cell packing density and a strategy which attempts to balance the illumination level on the VMJ cells across each junction.

The remainder of the paper is organized by presenting the developed HILPB system in Section 2.0, basic theory when connecting multiple cells in parallel in Section 3.0, Section 4.0 presents the results of a multi cell array optimizing the packing density, Section 5.0 presents the results of a multi cell array optimizing the illumination across each junction of a cell, and Section 6.0 presents the concluding results.

\subsection{The HILPB System}

The HILPB system is constructed around one subsystem to transmit the energy optically, and another to receive that energy and convert it back into electrical energy. The design and construction of the power receiver addresses four main issues. First, the receiver needs to provide sufficient thermal dissipation in order to handle the excess, electrically unconvertible energy. Second, the materials in the power receiver must have similar coefficients of thermal expansion to avoid stress fracturing during thermal cycling. Third, the electrical paths and connections in the receiver must feature low resistivity in order to maintain good end-to-end power efficiency. Lastly, the receiver must provide electrical isolation for the VMJ cells as well as the electrical routing and the interconnections.

The HILPB receiver has been designed around a highly efficient photovoltaic technology developed by scientists at NASA GRC for use in photovoltaic concentrator systems, known as VMJ cells. Utilizing a vertical configuration of $\mathrm{p}^{+} \mathrm{nn}+$ unit junctions (see Fig. 1), the VMJ photovoltaic cells offer unique advantages over the conventional planar solar cells; a typical cell has an area of approximately $0.8 \mathrm{~cm}^{2}$ and can withstand solar intensities that exceed 2500 suns.

The current HILPB system has been designed and constructed to enable in-air refueling capability for perpetual flight micro unmanned aerial vehicles (MUAVs) (Ref. 5). For this application, great considerations have been made in both the form factor and the weight of the developed hardware, to accelerate the integration of the prototype test articles and electronics into a working airframe. Materials such as aluminum nitride substrates, boron nitride epoxies, Kovar alloy conductors and silver paste adhesives were selected to meet the thermal, electrical and mechanical rigors of the receiver (Refs. 6 to 9). These materials were used to construct the HILPB receiver on the face of a thermal heat pipe unit, and a cross-sectional illustration of the material stack-up is shown in Figure 2.

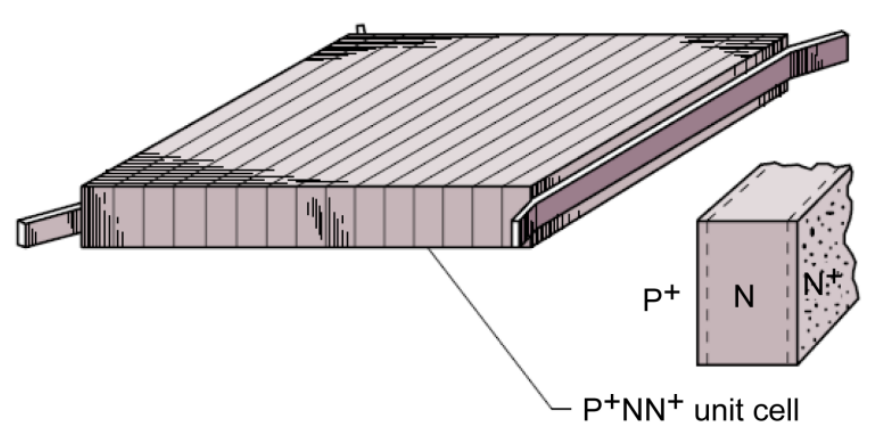

Figure 1.-A 40-junction silicon VMJ photovoltaic cell.

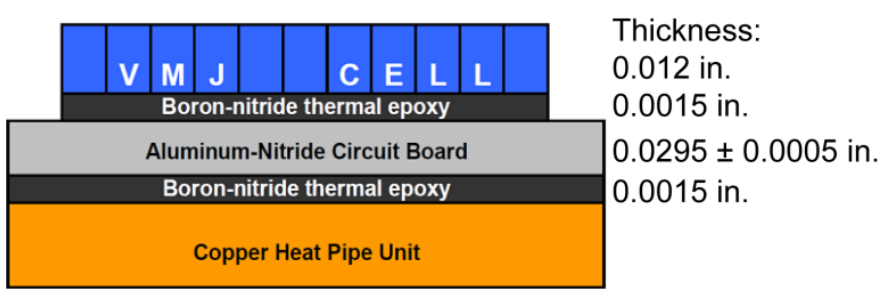

Figure 2.-Cross-sectional stackup of the power receiver. 
The power receiver is coupled with a system composed of high energy lasers and optics, custom data collection electronics and software, a power management and distribution system, and a variable load (Ref. 10). Various receivers have been constructed and evaluated with the system to investigate the effects of different cell arraying geometries, which are described in the next sections. These tests were conducted by the Industrial Space Systems Laboratory at Northrop Grumman's Laser Facility at Space Technology Park.

\subsection{Photovoltaic Array Cell Backfeeding}

The purpose of the initial series of tests was to investigate the potential for back-feeding of VMJ cells when they are wired in a parallel arrangement. This effect is encountered in a conventional solar array under conditions where the photovoltaic cells are subjected to non-uniform illumination (such as from partial shading or debris on the panel), and this is commonly solved by inserting blocking diodes between each cell and the array bus to prevent the current flow from back-feeding into a weaker cell. The downside of doing this is that a voltage drop will occur across the diodes during normal operation of the array, resulting in slightly lower array output power.

Since the beam profile of the laser is non-uniform, this phenomenon could be encountered when using a parallel array of VMJ cells for HILPB. To investigate this, an experiment was conducted on a multi-cell receiver, using two of the available VMJ cells (referred to as the top and left cell) connected in parallel. These particular cells were chosen because they represent two different grades of VMJ cells, with one offering consistently better performance than the other in the NASA GRC flash lamp range. This would establish the conditions for a natural imbalance to occur in the array, even if both cells received exactly equal illumination. This imbalance was exacerbated by obscuring the weaker grade cell so as to insure an imbalanced condition. Low-loss diodes were selected for the blocking application, and these could be introduced into the circuit to observe their effects. Ammeters were used to measure the amount and polarity of the individual branch current contributions from both cells.

The tests were conducted using a $200 \mathrm{~W}$ continuous wave $980 \mathrm{~nm}$ laser, with the beam illuminating the two cells in a manner as to allow for each to receive a similar profile. Both of the cells were oriented with the direction of their junctions aligned towards the center of the beam, so that they both received equivalent amounts and profile of illumination. The test was conducted with three different amounts of beam overfill to vary the overall profile illuminating the cells, and was repeated both with and without the blocking diodes in the circuit. The receiver temperature was maintained within 50 to $60{ }^{\circ} \mathrm{C}$ for the duration of the experiment using a variable speed cooling fan flowing air across the heat pipe unit. The results of

\begin{tabular}{|c|c|c|}
\hline Position & $\begin{array}{c}\text { Without diodes } \\
\text { current, } A\end{array}$ & $\begin{array}{c}\text { With diodes } \\
\text { current, } A\end{array}$ \\
\hline Top cell & 0.233 & 0.147 \\
\hline Left cell & -0.097 & 0.0 \\
\hline
\end{tabular}

Figure 3.-Cell back-feeding with small overfill.

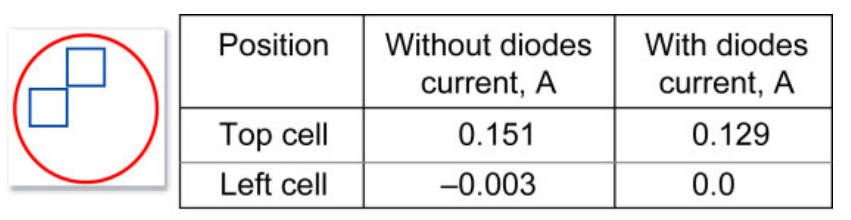

Figure 4.-Cell back-feeding with medium overfill.

\begin{tabular}{|c|c|c|c|}
\hline$\square$ & Position & $\begin{array}{c}\text { Without diodes } \\
\text { current, } A\end{array}$ & $\begin{array}{c}\text { With diodes } \\
\text { current, } A\end{array}$ \\
\hline Top cell & 0.189 & 0.122 \\
\hline Left cell & -0.087 & 0.004 \\
\hline
\end{tabular}

Figure 5.-Cell back-feeding with large overfill.

these tests are shown in Figures 3 to 5, and the relative diameter and placement of the beam overfill is illustrated.

The negative currents may be observed in the above tables when the blocking diodes are not present, and represent the back-feeding of the current from the strong cell (top) into the weak cell (left). The addition of the blocking diodes does correct the backflow, but at the expense of the inherent power loss through the diodes, to the extent that the diodes did not improve the overall output power of the receiver for any of the experimental results, and it was observed in these instances that their presence was more detrimental than beneficial. This is due to the diode losses exceeding the branch current gains, leading to a decrease in bulk output power.

It is therefore concluded that for HILPB applications, the use of blocking diodes as typically employed in photovoltaic arrays is not necessary. Furthermore, the detrimental receiver output power losses due to the inclusion of the blocking diodes exceeds the parasitic losses induced from cell backfeeding. The omission of the diodes yields a receiver design with fewer components, and permits a further investigation into receiver geometries as presented in the next two sections.

\subsection{9-Cell Square Array}

To explore the hypothesis of an alternate cell configuration and quantify the degree of its improvement, two receiver geometries are considered, a 9-cell square array and a 9-cell radial orientation array. The 9-cell square array simply orients all of the $\mathrm{p}^{+\mathrm{nn}+}$ junctions for each cell in the same direction, which optimizes packing density but generates the maximum possible junction-to-junction output variation when illuminated with a Gaussian laser beam. The receiver is 
constructed in a similar manner to the initial HILPB prototype (Ref. 10), and is hard-wired to provide three separate stacks of three paralleled cells (Fig. 6). For the purposes of these tests each stack is electrically connected together to produce a total of nine parallel cells.

The first objective of the experiment was to establish a baseline maximum power measurement for the subsequent tests. The 9-cell square receiver was illuminated with a $980 \mathrm{~nm}$ fibercoupled laser. The receiver position was adjusted in three axes to obtain the maximum output power with the laser's radiant power set to $200 \mathrm{~W}$, and the crest of this procedure resulted in a 30 percent illumination as depicted in the Figure 7. The peak output of the receiver in this configuration was measured to be $23 \mathrm{~W}$, and the temperature at the heat pipe face was regulated within 50 to $60^{\circ} \mathrm{C}$ during the test.

The $23 \mathrm{~W}$ result represents a receiver with the maximum photovoltaic cell packing density, and with no regard for accommodating the non-uniform profile of the impinging beam. In the next section an alternate receiver geometry will be compared with this baseline figure.

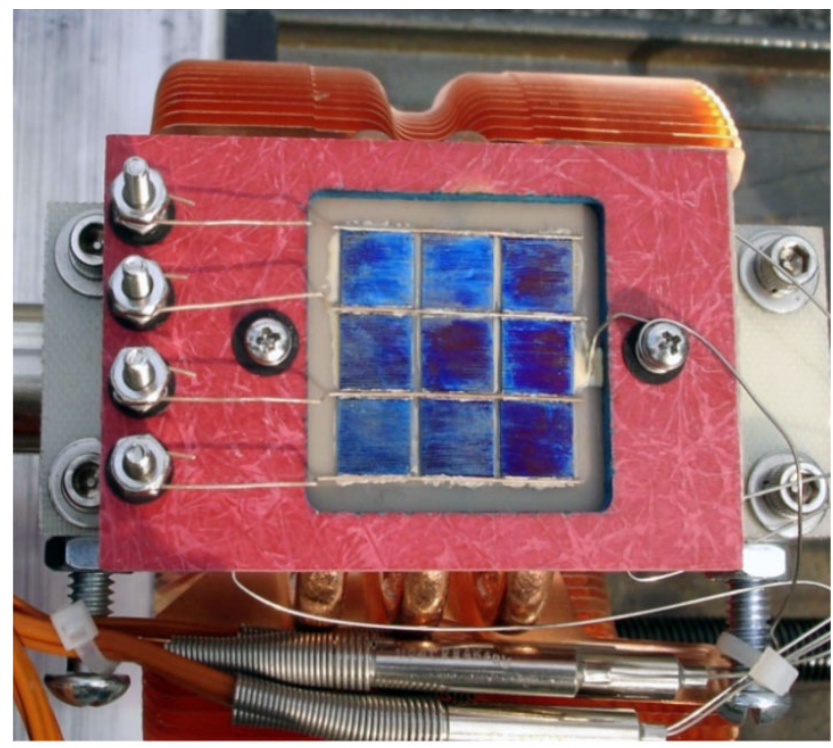

Figure 6.-Nine-cell square receiver.

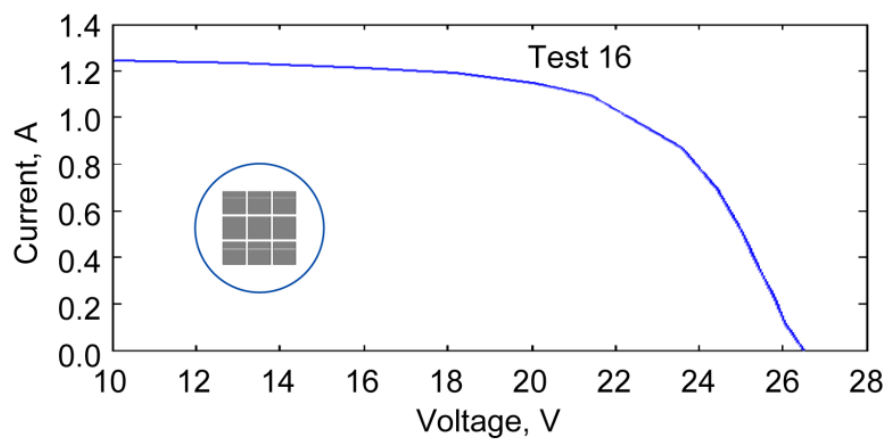

Figure 7.-Square receiver at $30 \%$ beam overfill, $23 \mathrm{~W}, \mathrm{P}_{\mathrm{mp}}$.

\subsection{9-Cell Radial Array}

The 9-cell radial orientation array places all of the junctions in eight of the cells on a radial to the center-point of the receiver (Fig. 8). When centered with the laser beam, the Gaussian profile will extend down the length of each p+nn+ junction, rather than appear across the junctions. In this way, the junction-to-junction delta is minimized, resulting in an equal average illumination per cell. A compromise to this rule is made by placing a single cell at the center of the array, for the purpose of maximizing packing density.

In this design each cell has its own dedicated pair of electrical leads, and as a design tradeoff to implement the radial concept it can be seen that the packing density is much lower than 9-cell square array. This receiver also features two additional miniature VMJ cells mounted in the vacant triangular corners, which were not used for this test.

For the next part of the experiment, the radial orientation receiver was used with all 9 of the 40-junction VMJ cells connected in a parallel arrangement. The same conditions were used as with the previous test to align the receiver at full (200 W) laser radiant power, starting with the inner grouping of five cells. The z-axis was adjusted to achieve a range that would maximize the overall power converted by the receiver array, resulting in a peak overfill condition. Each of the individual cells in the array were then disconnected and characterized in order to determine their contribution to the overall output of the receiver. The resulting output I-V curves are shown below in Figures 9 to 13, and the relative diameter and placement of the beam overfill is illustrated.

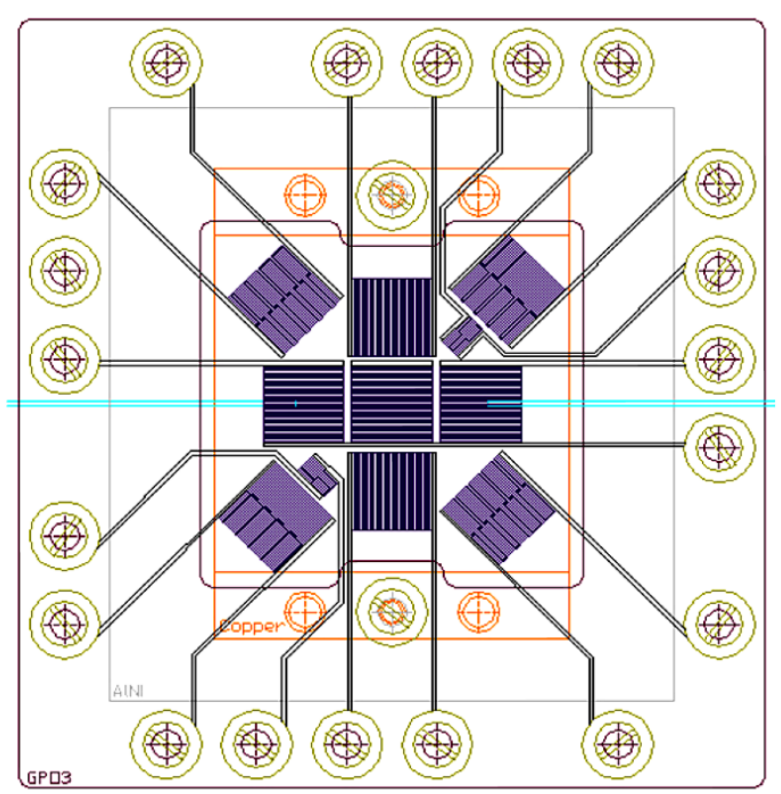

Figure 8.-CAD layout of the radial orientation receiver design. 


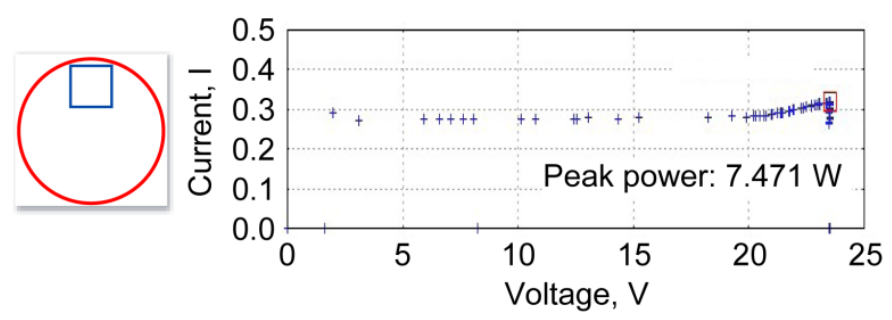

Figure 9.-Top cell I-V curve, 7.471 W, $\mathrm{P}_{\mathrm{mp}}$.

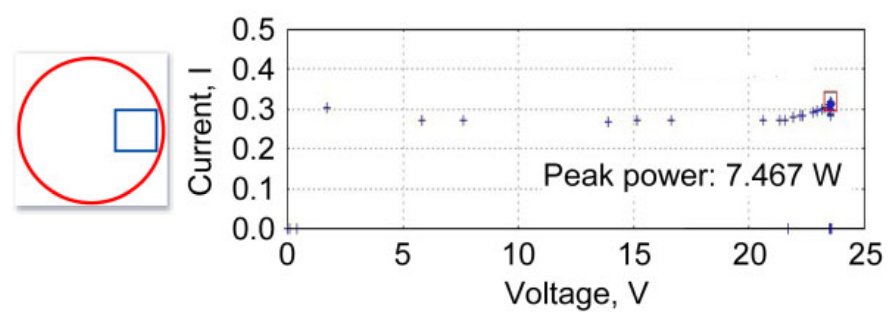

Figure 10.-Right cell I-V curve, $7.467 \mathrm{~W}, \mathrm{P}_{\mathrm{mp}}$.

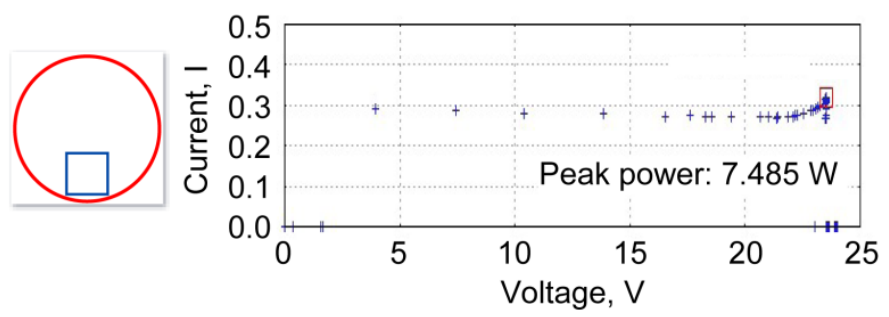

Figure 11.-Bottom cell I-V curve, $7.485 \mathrm{~W}, \mathrm{P}_{\mathrm{mp}}$.

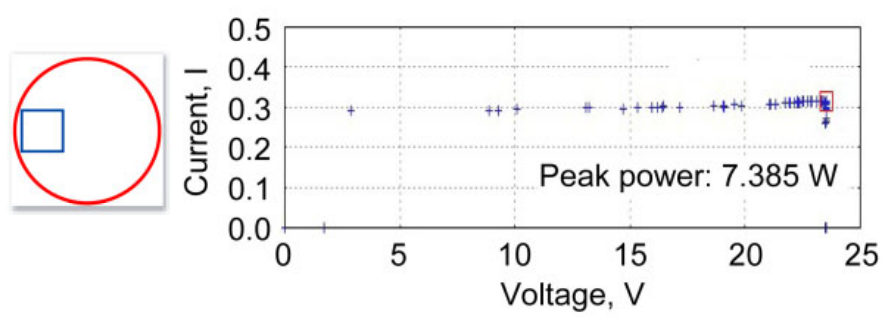

Figure 12.-Left cell I-V curve, 7.385 W, $\mathrm{P}_{\mathrm{mp}}$.

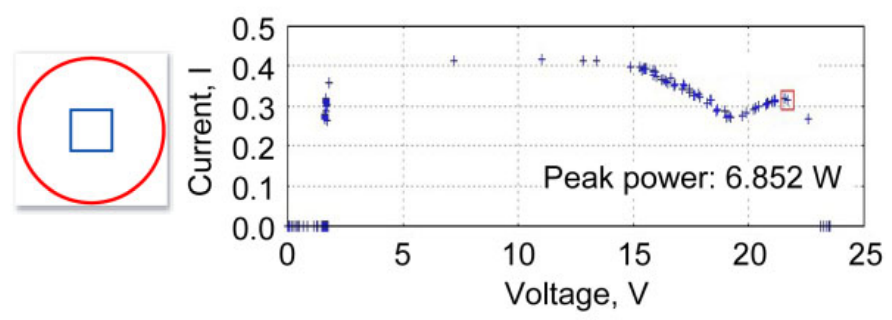

Figure 13.-Center cell I-V curve, $6.852 \mathrm{~W}, \mathrm{P}_{\mathrm{mp}}$.
It is interesting to note that the center cell, where the beam profile contains the most energy, did not have a higher output power than the four immediately surrounding cells. This may be attributed to the fact that unlike the surrounding cells, the center cell does not comply with the radial configuration, and even though it is receiving the highest intensity portion of the laser beam, it is unable to convert the energy efficiently since it is seeing an uneven power distribution across its $\mathrm{p}^{+} \mathrm{nn}+$ junctions. This is an indication into the magnitude of the detrimental effect of uneven power distribution across the $\mathrm{p}+\mathrm{nn}+$ junctions, and is also a first glimpse into the validity of the radial arrangement of the surrounding cells.

For the next part of the test, data sets were collected from both the inner four and five cell arrangements wired in parallel. These tests were performed with an optical alignment illuminating the five inner cells and at the $200 \mathrm{~W}$ laser power level. The resulting output I-V curves are shown below in Figures 14 and 15, and the relative diameter and placement of the beam overfill is illustrated.

A comparison of the results obtained in the grouped cell tests with the single cell tests shows that the four inner cells are again contributing the majority of the radial receiver's total output. Although the center cell is illuminated by the most intense part of the laser beam, it is converting less energy than its four individual neighboring cells. As stated earlier, this may be attributed to the center cell not complying with the radial configuration.

The five-cell output power of $23.935 \mathrm{~W}$ was calculated to have an optical-to-electrical conversion efficiency of 22.75 percent based on the overfill level of the beam. Comparing these results with those of the square array demonstrates that five cells in the radial orientation can

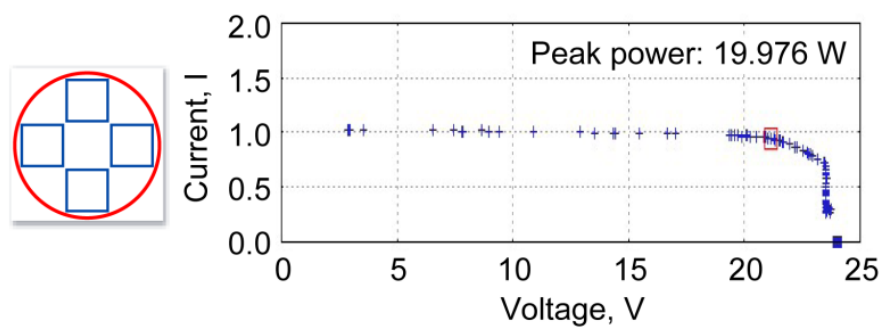

Figure 14.-Four-Cell I-V Curve, 19.976 W, P $\mathrm{mp}$.

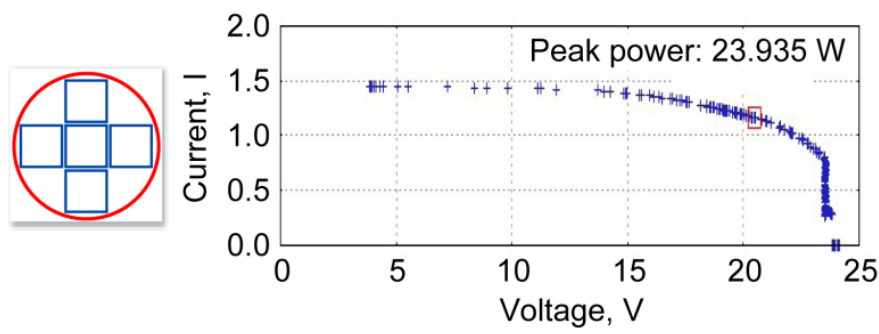

Figure 15.-Five cell I-V curve, $23.935 \mathrm{~W}, \mathrm{P}_{\mathrm{mp}}$. 


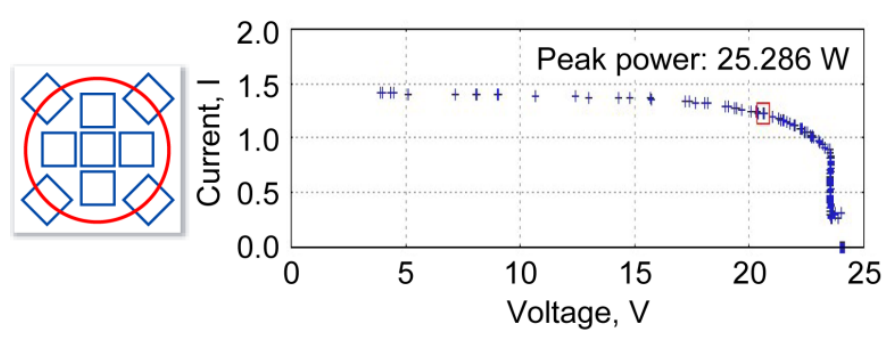

Figure 16. $-48.09 \%$ illum., $25.286 \mathrm{~W}, \mathrm{P}_{\mathrm{mp}}$ at $26.2 \% \eta$.

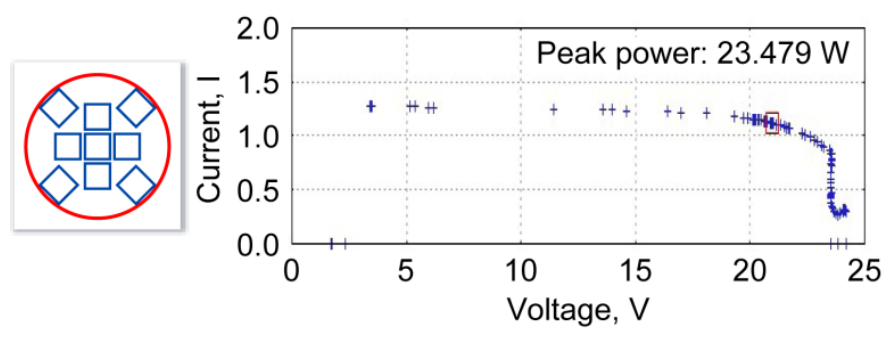

Figure 17.-37.72\% illum., $23.479 \mathrm{~W}, \mathrm{P}_{\mathrm{mp}}$ at $31.12 \% \eta$.

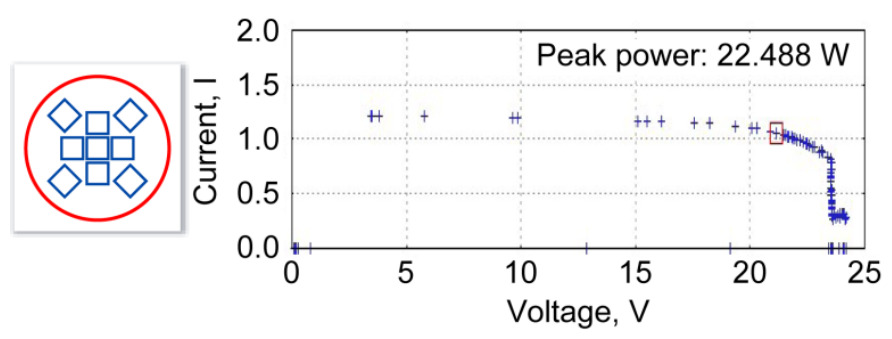

Figure 18.-25.24\% illum., $22.488 \mathrm{~W}, \mathrm{P}_{\mathrm{mp}}$ at $44.39 \% \eta$.

outperform nine cells in the square orientation, even with the packing density losses, providing further validation of the radial array concept.

For the final portion of the test, the overfill level of the receiver was incrementally increased to involve more of the corner cells in the overall output. As with all of the previous parts of this experiment the laser was operated at $200 \mathrm{~W}$, and the receiver temperature was regulated within 50 to $60^{\circ} \mathrm{C}$. The results may be observed in Figures 16 to 18 .

The smallest beam overfill level (Fig. 16) yielded the highest output power generated by a receiver during the experiment, at $25.206 \mathrm{~W}$. At this level of overfill, the opticalto-electrical conversion efficiency was calculated to be 26.2 percent. The highest optical-to-electrical conversion efficiency was found to be with the largest beam overfill level,

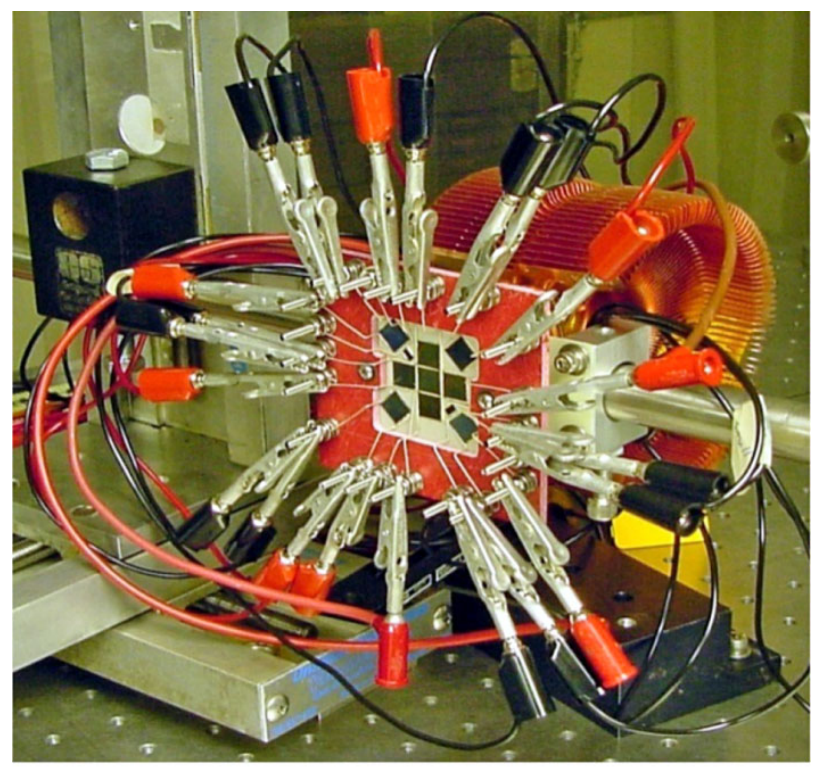

Figure 19.-9-cell radial array in the Northrop Grumman laser facility.

at 44.39 percent, but this occurred at the expense of total receiver output power dropping to $22.488 \mathrm{~W}$. The receiver setup used to achieve these experiments is shown in Figure 19.

\subsection{Conclusions and Future Work}

In summary, the radial orientation of the $\mathrm{p}+\mathrm{nn}+$ junctions was able to generate over $25 \mathrm{~W}$ of continuous output power from only 9 small VMJ cells, and under different overfill levels the same receiver was able to achieve 44.39 percent optical-to-electrical conversion efficiency. This demonstrates one potential solution to the Gaussian distribution issue, by outperforming the peak performance obtained from the conventional 9-cell square receiver array.

Future work in manufacturing chevron-shaped VMJ cells will have further potential improvements on array performance, by increasing the packing density in a radial array. A different approach may be to investigate the possibility of manufacturing curved junctions within the cell, to inversely match the profile of the impinging beam.

Further studies into investigating other laser frequencies or more complex optical illumination strategies will also have an impact on the overall receiver performance, and will be carried out to determine system impact. It is the opinion of the research team that the results presented in this paper demonstrates that HILPB reliably achieves significant performance levels for a wide range of missions or operations, and is scalable to achieve larger energy demands. 


\section{References}

1. B.L. Sater, N.D. Sater, "High voltage silicon VMJ solar cells for up to 1000 suns intensities," Photovoltaic Specialists Conference, 2002. Conference Record of the Twenty-Ninth IEEE, Publication Date: 19-24 May 2002, on page(s): 1019- 1022, ISSN: 1060-8371, ISBN: 07803-7471-1.

2. C. Goradia, B.L. Sater, "A first order theory of the $p /+/-$ n-n/+/ edge-illuminated silicon solar cell at very high injection levels," IEEE Transactions on Electron Devices. Vol. ED-24, pp. 342-351. Apr. 1977.

3. D. Raible, "High intensity laser power beaming for wireless power transmission," Master's Thesis, Cleveland State University, May, 2008.

4. J. Alda, "Laser and Gaussian beam propagation and transformation," University Complutense of Madrid, Madrid, Spain, Encyclopedia of Optical Engineering, 2003.

5. T.H. Nayfeh, D. Raible, D. Dinca, D. Avanesian, "High intensity laser power beaming (HILPB) receiver to enable in-flight remote refueling of electric miniature unmanned aerial vehicles (MUAVs)," Final Program Report to the Eglin Air Force Research Laboratory, Industrial Space Systems Laboratory, Cleveland State University, February 15, 2010.
6. K. Miwa, A. Fukumoto, "First principles calculation of the structural, electronic and vibrational properties of gallium nitride and aluminum nitride," Physical Review B, Volume 48 Number 11, Spetember 15, 1993.

7. P. Bujard, "Thermal conductivity of boron nitride filled epoxy resins: temperature dependence and influence of sample preparation,” Ciba-Geigy Ltd., Fribourg; Thermal Phenomena in the Fabrication and Operation of Electronic Components: I-THERM '88, InterSociety Conference on; 11-13 May 1988.

8. G. Liu, B. Cui, R.J. Chen, “Thermal expansion behavior of copper/Kovar alloy composite,” Northeast Univ. Technol. (China). Vol. 9, no. 4, pp. 498-501. Dec. 1988.

9. SPI Silver Paste Plus datasheet, http://www.2spi.com/catalog/spec_prep/plus_prop.html

10. T.H. Nayfeh, B. Fast, D. Raible, D. Dinca, N. Tollis, A. Jalics, "High intensity laser power beaming architecture for space and terrestrial missions," Proceedings of the 18th AFRL/NASA Advanced Space Propulsion Workshop; November 15-17, 2010; University of Colorado at Colorado Springs, Colorado Springs, Colorado; (2010). 


\begin{tabular}{|c|c|c|}
\hline \multicolumn{2}{|c|}{ REPORT DOCUMENTATION PAGE } & $\begin{array}{l}\text { Form Approved } \\
\text { OMB No. 0704-0188 }\end{array}$ \\
\hline $\begin{array}{l}\text { 1. REPORT DATE (DD-MM-YYYY) } \\
01-03-2012\end{array}$ & $\begin{array}{l}\text { 2. REPORT TYPE } \\
\text { Technical Memorandum }\end{array}$ & 3. DATES COVERED (From - To) \\
\hline \multirow{3}{*}{\multicolumn{2}{|c|}{$\begin{array}{l}\text { 4. TITLE AND SUBTITLE } \\
\text { Comparison of Square and Radial Geometries for High Intensity Laser Power Beaming } \\
\text { Receivers }\end{array}$}} & 5a. CONTRACT NUMBER \\
\hline & & 5b. GRANT NUMBER \\
\hline & & 5c. PROGRAM ELEMENT NUMBER \\
\hline \multirow{2}{*}{\multicolumn{2}{|c|}{$\begin{array}{l}\text { 6. AUTHOR(S) } \\
\text { Raible, Daniel, E.; Fast, Brian, R.; Dinca, Dragos; Nayfeh, Taysir, H.; Jalics, Andrew, K. }\end{array}$}} & 5d. PROJECT NUMBER \\
\hline & & $\begin{array}{l}\text { 5f. WORK UNIT NUMBER } \\
\text { WBS 439432.07.01.17.02 }\end{array}$ \\
\hline \multicolumn{2}{|c|}{$\begin{array}{l}\text { 7. PERFORMING ORGANIZATION NAME(S) AND ADDRESS(ES) } \\
\text { National Aeronautics and Space Administration } \\
\text { John H. Glenn Research Center at Lewis Field } \\
\text { Cleveland, Ohio 44135-3191 }\end{array}$} & $\begin{array}{l}\text { 8. PERFORMING ORGANIZATION } \\
\text { REPORT NUMBER } \\
\text { E-18010 }\end{array}$ \\
\hline \multirow{2}{*}{\multicolumn{2}{|c|}{$\begin{array}{l}\text { 9. SPONSORING/MONITORING AGENCY NAME(S) AND ADDRESS(ES) } \\
\text { National Aeronautics and Space Administration } \\
\text { Washington, DC 20546-0001 }\end{array}$}} & $\begin{array}{l}\text { 10. SPONSORING/MONITOR'S } \\
\text { ACRONYM(S) } \\
\text { NASA }\end{array}$ \\
\hline & & $\begin{array}{l}\text { 11. SPONSORING/MONITORING } \\
\text { REPORT NUMBER } \\
\text { NASA/TM-2012-217255 }\end{array}$ \\
\hline
\end{tabular}

\section{SUPPLEMENTARY NOTES}

\section{ABSTRACT}

In an effort to further advance a realizable form of wireless power transmission (WPT), high intensity laser power beaming (HILPB) has been developed for both space and terrestrial applications. Unique optical-to-electrical receivers are employed with near infrared (IR-A) continuous-wave (CW) semiconductor lasers to experimentally investigate the HILPB system. In this paper, parasitic feedback, uneven illumination and the implications of receiver array geometries are considered and experimental hardware results for HILPB are presented. The TEM00 Gaussian energy profile of the laser beam presents a challenge to the effectiveness of the receiver to perform efficient photoelectric conversion, due to the resulting non-uniform illumination of the photovoltaic cell arrays. In this investigation, the geometry of the receiver is considered as a technique to tailor the receiver design to accommodate the Gaussian beam profile, and in doing so it is demonstrated that such a methodology is successful in generating bulk receiver output power levels reaching $25 \mathrm{~W} \mathrm{from} 7.2 \mathrm{~cm}{ }^{2}$ of photovoltaic cells. These results are scalable, and may be realized by implementing receiver arraying and utilizing higher power source lasers to achieve a $1.0 \mathrm{~m}^{2}$ receiver capable of generating over $30 \mathrm{~kW}$ of electrical power. This type of system would enable long range optical "refueling” of electric platforms, such as MUAV's, airships, robotic exploration missions and provide power to spacecraft platforms which may utilize it to drive electric means of propulsion. In addition, a smaller HILPB receiver aperture size could be utilized to establish a robust optical communications link within environments containing high levels of background radiance, to achieve high signal to noise ratios.

15. SUBJECT TERMS

Optics; Photonics; Laser power beaming; Wireless power transmission

\begin{tabular}{|l|l|l|l|}
\hline \multicolumn{2}{|l|}{ 16. SECURITY CLASSIFICATION OF: } & $\begin{array}{l}\text { 17. LIMITATION OF } \\
\text { ABSTRACT }\end{array}$ \\
\begin{tabular}{|l|l|l} 
a. REPORT \\
$U$
\end{tabular} & $\begin{array}{l}\text { b. ABSTRACT } \\
\text { A }\end{array}$ & $\begin{array}{l}\text { C. THIS } \\
\text { PAGE } \\
U\end{array}$ & UU \\
\hline
\end{tabular}

\begin{tabular}{|l|l|}
\hline $\begin{array}{l}\text { 18. NUMBER } \\
\text { OF } \\
\text { PAGES }\end{array}$ & $\begin{array}{l}\text { 19a. NAME OF RESPONSIBLE PERSON } \\
\text { STI Help Desk (email:help@sti.nasa.gov) }\end{array}$ \\
\cline { 2 - 2 } & $\begin{array}{l}\text { 19b. TELEPHONE NUMBER (include area code) } \\
\text { 443-757-5802 }\end{array}$ \\
\hline
\end{tabular}


